\title{
The Association Between the Pattern of Electronic Cigarette Smoking and Gastroesophageal Reflux
}

\author{
Ahmad Fariz Malvi Zamzam Zein*,**, Donny Nauphar***, Uswatun Khasanah****, \\ Tiar M Pratamawati***, Rama S Brajawikalpa****, Eka Ayuningtyas*****, Alif \\ $\operatorname{Hamzah}^{* * * * * * *}$ \\ *Department of Internal Medicine, Faculty of Medicine, Universitas Swadaya Gunung Jati, \\ Cirebon \\ ${ }^{* *}$ Department of Internal Medicine, Waled General Hospital, Cirebon \\ ${ }^{* * *}$ Department of Genetics, Faculty of Medicine, Universitas Swadaya Gunung Jati, Cirebon

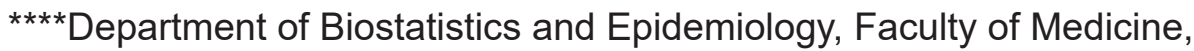 \\ Universitas Swadaya Gunung Jati, Cirebon \\ *****Department of Pharmacology, Faculty of Medicine, Universitas Swadaya Gunung Jati, \\ Cirebon \\ ${ }^{* * * * * *}$ Department of Dentistry, Waled General Hospital, Cirebon \\ ${ }^{* * * * * * *}$ Faculty of Medicine, Universitas Swadaya Gunung Jati, Cirebon
}

\section{Corresponding author:}

Ahmad Fariz Malvi Zamzam Zein. Department of Internal Medicine, Waled General Hospital. Jln Taman Pemuda 2 Kompleks Stadion Bima Cirebon Indonesia. Phone: +62-231-483928; facsimile: +62-231-488923. E-mail:fariz_zein_dr@yahoo.com

\section{ABSTRACT}

Background: This study was aimed to investigate the proportion of gastroesophageal reflux (GER) among electronic cigarette (e-cig) smokers and its association with the pattern of e-cig smoking.

Method: This cross-sectional study underwent among e-cig smokers community in Cirebon City, Jawa Barat, ranged from March to August 2020. Subjects were enrolled through consecutive sampling method. The data collection used survey containing the pattern of e-cig smoking and GER. The pattern of e-cig smoking included the duration of e-cig smoking and the amount of e-cig smoking. Gastroesophageal reflux consisted of GER-related symptoms (heartburn, regurgitation, and nocturnal symptom) and gastroesophageal reflux disease (GERD). GERD was defined as GERD questionnaire score cut-off $\geq 8$. Data analysis used chi square test. This study has been approved by The Medical Research Ethics Committee, Faculty of Medicine, Universitas Swadaya Gunung Jati.

Results: There were 273 respondents in this study. The proportion of heartburn was $6.6 \%, 10.3 \%$ for regurgitation, 3.7\% for nocturnal symptom, and 5.5\% for GERD. There was no association between duration of e-cig smoking and heartburn ( $p$ 0.681), regurgitation ( $p$ 0.568), nocturnal symptom ( $p$ 0.764), and GERD ( $p$ $0.113)$. There was no association between amount of e-cig smoking and heartburn ( $p$ 0.062), regurgitation ( $p$ 0.770), nocturnal symptom ( $p$ 0.985), and GERD ( $p$ 0.605).

Conclusion: There was relatively low proportion of GER among e-cig smokers. There was no association between the pattern of e-cig smoking and GER in this study.

Keywords: electronic cigarette smoking; gastroesophageal reflux; symptoms; gastroesophageal reflux disease 


\section{ABSTRAK}

Latar belakang: Studi ini bertujuan untuk mengetahui proporsi refluks gastroesofagus (RGE) pada perokok elektrik dan hubungan antara pola konsumsi rokok elektrik dengan $R G E$.

Metode: Studi potong lintang ini dilakukan terhadap komunitas perokok elektrik di Kota Cirebon, Jawa Barat, selama Maret-Agustus 2020. Metode pengambilan sampel pada studi ini adalah consecutive sampling method. Pengumpulan data menggunakan survei yang berisikan tentang pola konsumsi rokok elektrik dan RGE. Pola konsumsi rokok elektrik meliputi lama konsumsi rokok elektrik dan jumlah konsumsi rokok elektrik. Refluks gastroesofagus pada studi ini terdiri dari gejala terkait RGE (heartburn, regurgitasi, dan gejala nokturnal) dan penyakit refluks gastroesofagus (PRGE). Status PRGE didefinisikan berdasar skor menggunakan Gastroesophageal reflux diseases questionnaire (GERDQ) tervalidasi dalam bahasa Indonesia dengan nilai potong $\geq 8$. Studi ini telah mendapat klirens etik dari Komite Etik Penelitian Kesehatan Fakultas Kedokteran Universitas Swadaya Gunung Jati.

Hasil: Terdapat 273 responden pada studi ini. Proporsi gejala terkait RGE yaitu 6,6\% untuk heartburn, 10,3\% untuk regurgitasi, 3,7\% untuk gejala nokturnal. Didapatkan proporsi PRGE 5,5\% pada studi ini. Tidak terdapat hubungan yang bermakna antara lama konsumsi rokok elektrik dengan heartburn $(p=0,681)$, regurgitasi $(p=$ $0,568)$, gejala nokturnal $(p=0,764)$, dan PRGE $(p=0,113)$. Tidak terdapat hubungan yang bermakna antara jumlah konsumsi rokok elektrik dengan heartburn $(p=0,0682)$, regurgitasi $(p=0,770)$, gejala nokturnal $(p=$ 0,985), dan PRGE ( $p=0,605)$.

Simpulan: Proporsi RGE pada perokok elektrik relatif rendah. Tidak didapatkan hubungan yang bermakna antara pola konsumsi rokok elektrik dan RGE pada studi ini.

Kata kunci: rokok elektrik; refluks gastroesofagus; gejala; penyakit refluks gastroesofagus

\section{INTRODUCTION}

Electronic cigarette smoking is an emerging trend among adolescence and young adult recently. This trend has developed rapidly and globally. The surging assumptions and robust marketing have established the e-cig smoking as an alternative tool with healthier, less toxic, and non-addictive smoking cessation method. These assumptions have brought large contribution on e-cig smokers' interest and the conversion from conventional cigarette smokers to e-cig smokers. Nevertheless, there is still limited study regarding the impact of e-cig smoking on health concern.

Gastroesophageal reflux refers to the condition of gastric content reflux to esophagus. gastroesophageal reflux (GER) may manifest as episodic GER-related symptoms and gastroesophageal reflux disease (GERD). GERD predominates globally in primary healthcare and implicates on patients' quality of life. Pathophysiology of GERD is still evolving and multifactorial disease. Obesity and some lifestyle are well-known risk factors of GERD. The interventions of lifestyle-related risk factors are associated with improvement in clinical condition and quality of life.

The tobacco smoking is one of common risk factor for GERD and smoking cessation is related to symptom reduction. To the best our knowledge, there is no study investigating the association between e-cig smoking and GER. This study was aimed to measure the proportion of GER among e-cig smokers and to evaluate the relationship between pattern of e-cig smoking and GER-related symptoms, and GERD as well.

\section{METHOD}

This descriptive analytic study used cross-sectional study design. The study was held on Cirebon City, Jawa Barat, Indonesia, ranged from March to August 2020. Subjects were the member of communities of e-cig smokers. Persons with known history of dyspepsia or GERD before e-cig smoking were excluded. We used consecutive sampling method in this study.

The instrument used in this study was survey to determine baseline characteristics of respondents, the pattern of e-cig smoking, and GER. Baseline characteristics included demographic characteristic (gender, age, ethnic, level of income). The pattern of e-cig smoking consisted of the duration of e-cig smoking and the amount of e-cig smoking. The duration of e-cig smoking was categorized into less than 2 year and more than 2 year. The amount of e-cig smoking in this study was stated in $\mathrm{mL}$ per week and was categorized into less than $40 \mathrm{~mL} /$ week 
and more than $40 \mathrm{~mL} /$ week. GER included GERrelated symptoms and GERD. GER-related symptom comprised heartburn, regurgitation, and nocturnal symptoms. Heartburn was defined as the burn sensation on lower chest during daytime less than twice a week. Regurgitation was defined as the sensation of bringing swallowed food up again to mouth during daytime less than twice a week. Nocturnal symptom was defined as heartburn and/or regurgitation during nighttime less than twice a week. GERD status was measured by validated GERD questionnaire (GERDQ) in Indonesian language. GERD was defined as GERDQ score $\geq 8$.

Data from survey were cleaned and exported to IBM SPSS Statistics 23.0. Numerical data were summarized as means and standard deviations or median and range as appropriate. Categorical data were summarized as frequency and percentage. Proportions were summarized in percentage. Bivariate analysis was using chi square test and $p$ value less than 0.05 was determined as statistically significance.

This study has been approved by the Medical Research Ethics Committee, Faculty of Medicine, Universitas Swadaya Gunung Jati, Indonesia.

\section{RESULTS}

There were 273 respondents in study with predominantly male $(94.2 \%)$. The baseline characteristic is available at Table 1 . The median age of respondents is 23 (17-48) years old. The most frequent ethnic was Javanese (68.5\%).

Table 1. Baseline characteristic of respondents

\begin{tabular}{ll}
\hline Characteristic & $\mathbf{n}(\%)$ \\
\hline Gender & $257(94.2)$ \\
Male & $16(5.9)$ \\
Female & \\
Age group (years old) & $76(27.8)$ \\
$\leq 20$ & $141(51.6)$ \\
$21-30$ & $50(18.3)$ \\
$31-40$ & $6(2.2)$ \\
$>40$ & \\
Ethnic & $187(68.5)$ \\
Javanese & $71(26.0)$ \\
Sundanese & $15(5.5)$ \\
Others & $187(68.5)$ \\
Marital status & $83(30.4)$ \\
Single & $3(1.1)$ \\
Married & \\
Divorce & $154(56.4)$ \\
Level of income & $83(30.4)$ \\
Low & $36(13.2)$ \\
Moderate & \\
High &
\end{tabular}

The pattern of e-cig smoking is available at Table 2 . The median of duration of e-cig smoking was 1 (1-12) year. The median of the amount of e-cig smoking was
$30(3-300) \mathrm{mL} /$ week.

Table 2. The pattern of electronic cigarette smoking

\begin{tabular}{ll}
\hline Pattern & $\mathbf{n}(\%)$ \\
\hline Duration of e-cig smoking (year) & $179(65.57)$ \\
$\quad \leq 2$ & $94(34.43)$ \\
$>2$ & $163(59.71)$ \\
Amount of e-cig smoking (mL/week) & $110(40.29)$ \\
$\quad \leq 40$ & \\
\hline$>40$ &
\end{tabular}

In this study, we had 18 (6.6\%) respondents having heartburn, $28(10.3 \%)$ regurgitation, and $10(3.7 \%)$ nocturnal symptoms. Further, there were 15 (5.5\%) respondents having GERD in this.

The association between the pattern of e-cig smoking and heartburn is shown at Table 3 . There was no association between duration of e-cig smoking and heartburn and there was no association between amount of e-cig smoking and heartburn as well.

Table 3. The association between the pattern of e-cig smoking and heartburn

\begin{tabular}{|c|c|c|c|c|}
\hline \multirow{2}{*}{$\begin{array}{c}\text { The pattern of e-cig } \\
\text { smoking }\end{array}$} & \multicolumn{2}{|c|}{ Heartburn } & \multirow[b]{2}{*}{ p } & \multirow[b]{2}{*}{ OR $(95 \% \mathrm{Cl})$} \\
\hline & No & Yes & & \\
\hline $\begin{array}{l}\text { Duration of e-cig smoking } \\
\text { (year) }\end{array}$ & & & & \\
\hline$\leq 2$ & 168 & 11 & 0.681 & $\begin{array}{c}1.229 \\
(0.460-3.282)\end{array}$ \\
\hline $\begin{array}{l}>2 \\
\text { Amount of e-cig smoking (mL/ } \\
\text { week) }\end{array}$ & 87 & 7 & & \\
\hline$\leq 40$ & 156 & 7 & 0.062 & $\begin{array}{c}2.476 \\
(0.929-6.601)\end{array}$ \\
\hline$>40$ & 99 & 11 & & \\
\hline
\end{tabular}

Abbreviation: e-cig = electronic cigarette

The association between the pattern of e-cig smoking and regurgitation is shown at Table 4. There was no association between duration of e-cig smoking and regurgitation and there was no association between amount of e-cig smoking and regurgitation as well.

Table 4. The association between the pattern of e-cig smoking and regurgitation

\begin{tabular}{|c|c|c|c|c|}
\hline \multirow{2}{*}{$\begin{array}{c}\text { The pattern of e-cig } \\
\text { smoking }\end{array}$} & \multicolumn{2}{|c|}{ Regurgitation } & \multirow[b]{2}{*}{ p } & \multirow{2}{*}{ OR $(95 \% \mathrm{Cl})$} \\
\hline & No & Yes & & \\
\hline $\begin{array}{l}\text { Duration of e-cig smoking } \\
\text { (year) }\end{array}$ & & & & \\
\hline$\leq 2$ & 162 & 17 & 0.568 & $\begin{array}{c}1.263 \\
(0.566-2.820)\end{array}$ \\
\hline $\begin{array}{l}\quad>2 \\
\text { Amount of e-cig smoking } \\
(\mathrm{mL} / \text { week })\end{array}$ & 83 & 11 & & \\
\hline$\leqq 40$ & 147 & 16 & 0.770 & $\begin{array}{c}1.125 \\
(0.510-2.481)\end{array}$ \\
\hline$>40$ & 98 & 12 & & \\
\hline
\end{tabular}

Abbreviation: e-cig = electronic cigarette

The association between the pattern of e-cig smoking and nocturnal symptom is available at Table 5. There was no association between duration of e-cig smoking and nocturnal symptom and also there was 
no association between amount of e-cig smoking and nocturnal symptom.

Table 5. The association between the pattern of e-cig smoking and nocturnal symptom

\begin{tabular}{|c|c|c|c|c|}
\hline \multirow{2}{*}{$\begin{array}{l}\text { The pattern of e-cig } \\
\text { smoking }\end{array}$} & \multicolumn{2}{|c|}{$\begin{array}{l}\text { Nocturnal } \\
\text { symptom }\end{array}$} & \multirow[t]{2}{*}{$p$} & \multirow[t]{2}{*}{ OR (95\% Cl) } \\
\hline & No & Yes & & \\
\hline \multicolumn{5}{|l|}{$\begin{array}{l}\begin{array}{l}\text { Duration of e-cig smoking } \\
\text { (year) }\end{array} \\
\text { (y) }\end{array}$} \\
\hline$\leq 2$ & 172 & 7 & 0.764 & $\begin{array}{c}0.810 \\
(0.205-3.208)\end{array}$ \\
\hline $\begin{array}{l}\quad>2 \\
\text { Amount of e-cig smoking } \\
(\mathrm{mL} / \text { week })\end{array}$ & 91 & 3 & & \\
\hline$\leq 40$ & 157 & 6 & 0.985 & $\begin{array}{c}0.987 \\
(0.272-3.583)\end{array}$ \\
\hline$>40$ & 106 & 4 & & \\
\hline
\end{tabular}

e-cig = electronic cigarette

The association between the pattern of e-cig smoking and GERD is revealed at Table 6 . There was no association between duration of e-cig smoking and GERD and there was no association between amount of e-cig smoking and GERD as well.

Table 6. The association between the pattern of e-cig smoking and GERD

\begin{tabular}{llllc}
\hline $\begin{array}{l}\text { The pattern of e-cig } \\
\text { smoking }\end{array}$ & \multicolumn{2}{c}{ GERD } & & \multirow{2}{*}{ OR $(95 \% \mathrm{Cl})$} \\
\cline { 2 - 3 } $\begin{array}{l}\text { Duration of e-cig smoking } \\
\text { (year) }\end{array}$ & No & & & \\
$\quad \leq 2$ & 172 & 7 & 0.113 & 2.286 \\
$\quad>2$ & 86 & 8 & & $(0.802-6.511)$ \\
$\begin{array}{l}\text { Amount of e-cig smoking } \\
\text { (mL/week) }\end{array}$ & & & \\
$\quad \leq 40$ & 155 & 8 & 0.605 & $\begin{array}{c}1.317 \\
\quad>40\end{array}$ \\
\hline
\end{tabular}

e-cig: electronic cigarette; GERD: gastroesophageal reflux disease

\section{DISCUSSION}

E-cig smoking is a relatively new nicotine delivery system founded first 2003 in China. ${ }^{1}$ It is an alternative smoking cessation method and some marketing further claimed that it is less toxic than tobacco smoking. ${ }^{2}$ To the best our knowledge, this is the first study concerning about the relationship between e-cig smoking and GERD. Cross-sectional study used in this study was aimed to estimate GERD among e-cig smokers and further to investigate the potential causal associations between exposure (e-cig smoking) and outcome (GER). Most of e-cig smokers, well-known as vaper, are youth, high level of income, and urban population..$^{1-4}$ This study demonstrated that the most age group of e-cig smokers was young adult population. This is due to subjects in this study were relatively homogenous as members of e-cig smoker community. This study also showed that e-cig smokers were mostly with low level of income. This might be due to its low price of e-cig smoke in the city.

E-cig smoking has been recently a public health issue due to its uncertainty of potential health impact on its efficacy as smoking cessation method. Otherwise, there is still limited study of its safety. One concern on health issue of e-cig smoking is nicotine as the content. Relating its impact on upper gastrointestinal tract, nicotine reduces lower esophageal sphincter (LES) pressure enabling reflux of gastric content into esophagus. ${ }^{5-6}$ Studies showed also that tobacco smoking is associated with prolongation of esophageal acid clearance time. ${ }^{5-6}$ Some studies showed that tobacco smoking is risk factor for GERD and smoking cessation implicates clinical improvement and GERD-related quality of life. ${ }^{6-10}$ Yet, there is no study concerning the association between e-cig smoking and GER. Jessica et al reported that as much as $1.6 \%$ e-cig smokers complained nausea as adverse event but its relationship was not revealed. ${ }^{11}$ Our study showed that the proportion of GER-related symptoms and GERD were low among e-cig smokers. This study further demonstrated that there was neither association between the pattern of e-cig smoking and GER-related symptoms or GERD. We assumed that short duration of e-cig smoking with its median 1 year in this study may contribute its relatively low exposure. The amount of e-cig smoking in this study may not be in accordance with the accurate dose of nicotine exposure to measure dose-response relationship as well. Another assumption is concerning about level of nicotine in e-cig is much lower than level of nicotine in tobacco cigarette. This may contribute less or smaller impact on LES pressure reduction.

Limitation of this study is survey method using questionnaire enabling recall bias. It is necessary to enroll larger sample size which is more representative toward population. It is also needed to formulate the amount of e-cig smoking so we can measure the doseresponse relationship.

\section{CONCLUSION}

The proportion of GER among averagely 1-year e-cig smoker is low. There is no association between the pattern of e-cig smoking and GER. Further studies are needed with larger sample size and better measurement on nicotine exposure of e-cig smoking to establish dose-response relationship.

\section{REFERENCES}


1. Meo SA, Al Asiri SA. Effects of electronic cigarette smoking on human health. Eur Rev Med Pharmacol Sci 2014;18:3315-9.

2. Drummond MB, Upson D. Electronic cigarettes potential harms and benefits. Ann Am Thorac Soc 2014;11:236-42.

3. Ferkol TW, Farber HJ, La Grutta S, Leone FT, Marshall HM, Neptune E, et al. Electronic cigarette use in youths: a position statement of the Forum of International Respiratory Societies. Eur Respir J 2018;51:1800278.

4. Besaratinia A, Tommasi S. An opportune and unique research to evaluate the public health impact of electronic cigarettes. Cancer Causes Control 2017:0952-5.

5. Pandolfino JE, Kahrilas PJ. Smoking and gastro-oesophageal reflux disease. Eur J Gastroenterol Hepatol 2000;12:837-42.

6. Ness-Jensen E, Lagergren J. Tobacco smoking, alcohol consumption and gastro-oesophageal reflux disease. Best Practice \& Research Clinical Gastroenterology 2017; 31:501-8.

7. Nilsson M, Johnsen R, Ye W, Hveem K, Lagergren J. Lifestyle related risk factors in the aetiology of gastro-oesophageal reflux 2004;53:1730-5.

8. Eusebi LH, Ratnakumaran R, Yuan Y, Solaymani-Dodaran M, Bazzoli F, Ford AC. Global prevalence of, adn risk fators fro, gastro-oesophageal reflux symptoms: a meta-analysis. Gut 2017;0:1-11.

9. Ness-Jensen E, Hveem K, El-Serag H, Lagergren J. Lifestyle intervention in gastroesophageal reflux disease. Clin Gastroenetrol Hepatol 2016;14:175-82.

10. Kohata Y, Fujiwara Y, Watanabe T, Kobayashi M, Takemoto Y, Kamata N, et al. Long-term benefits of smoking cessation on gastroesophageal reflux disease and health-related quality of life. PLoS ONE 2016;11:e0147860.

11. King JL, Reboussin BA, Wiseman KD, Ribisl KM, Seidenberg $\mathrm{AB}$, Wagoner KG, et al. Adverse symptoms users attribute to e-cigarettes: results from a national survey of US adults. Drug Alcohol Depend 2019;196:9-13. 